Ananthology of Scientific Articles IV: ANEW BEGINNING

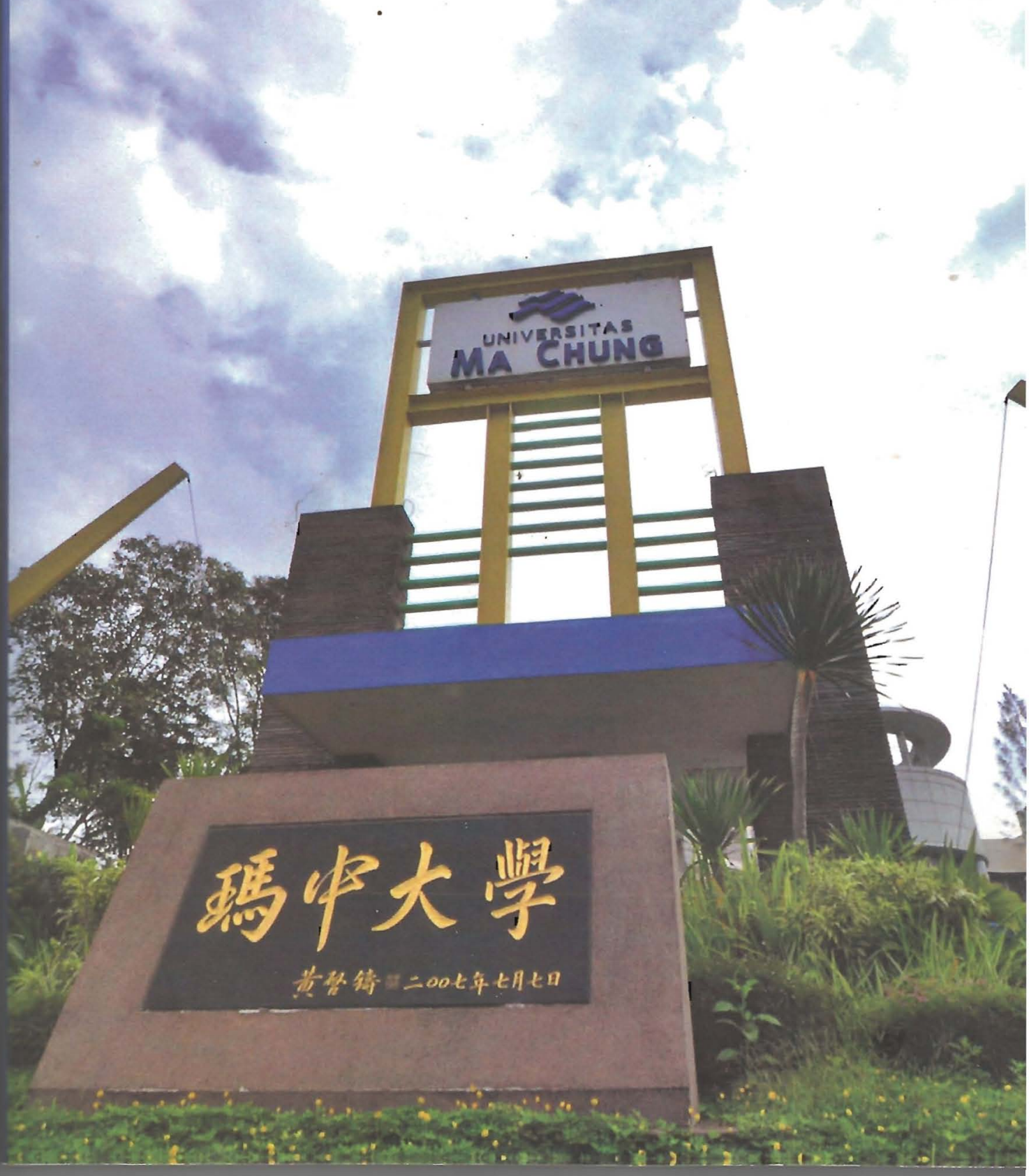




\section{thology of Scientific Articles IV: \\ $\checkmark$ Beginning}

ivitas Academica Universitas Ma Chung Malang

\section{ota (c) 2011 pada Penulis}

ipta dilindungi undang-undang. Dilarang memperbanyak atau lahkan sebagian atau seluruh isi buku ini dalam bentuk apapun, baik elektronis maupun mekanis, termasuk memfotocopy, merekam atau sistem penyimpanan lainnya, tanpa izin tertulis dari Penulis.

Prof. Eugenius Sadtono,Ph.D

Prof. Su Yun Lin, PhD

Prof. DR.Patrisius Istiarto Djiwandono

Ir. Stefanus Yufra Menahen Taneo, M.S, M.Sc

Daniel Ginting, SS., M.PC

Lindawati, Ph.D.

Etsa Astridya Setiyati, SE, PGDipBus., M.Com

Lilis Lestari Wilujeng,S.S, M.Hum

Rudy Setiawan, S.Si., MT

cover : Sugeng Riadi, S.T.

oditor : Irfan Tri Raharjo, S.E.

: Ma Chung Press

Jl. Villa Puncak Tidar N-01

Malang-Indonesia

\section{Perpustakaan Nasional: Katalog dalam Terbitan}

vitas Academica Universitas Ma Chung Malang An Anthology of Scientific Articles IV: A New Beginning. Malang: Ma Chung Press.

$i+268 \mathrm{hlm} ; 14,8 \times 21 \mathrm{~cm}$

BN: 978-602-9155-02-0

\section{KATA PENGANTAR}

A New Beginning merupakan sebuah sejarah baru perkembangan publikasi di Universitas Ma Chung. Sedikit berbeda dengan tahun seluelumnya, setiap naskah yang dimuat dalam Buku Anthology of science ini telah melalui proses review yang dilakukan oleh para dosen yang ahli dalam bidangnya.

Buku ini merupakan permulaan dimulainya era baru peningkatan kualitas publikasi di lingkup Universitas Ma Chung. Topik yang dihahas dalam buku ini meliputi Teknologi Industri dan IImu Rekayasa, Ilmu-IImu Sosial dan Ekonomi serta Budaya dan Teknologi Pembelajaran. Harapan kedepan semoga materi dan topik dalam huku ini dapat terus berkembang baik dari segi kualitas maupun kuantitas seiring dengan semakin berkembangnya Universitas $\mathrm{Ma}$ chung.

Ueapan terima kasih disampaikan kepada semua pihak, khususnya kepada Tim Reviewer naskah buku Anthology of Science IV yang telah memberikan banyak masukan dan membuat suatu pedoman tata penulisan artikel.

Malang, 7 Juli 2011

\section{Anna Triwijayati, SE, M.Si \\ DIREKTUR LPPM}


nced Scorecard sebagai Strategi Penilaian Kinerja

sahaan

thala Manalu

nesian Sovereign Risk:

it The Credit Default Swap Is Telling Us?

ienartomo Soepomo Moch Doddy Ariefianto

yaruh Resiko Kurs, Resiko Suku Bunga terhadap

'it Ekspor dan Dokumen Ekspor.

ienartomo Soepomo

isis Sistem Pengendalian Internal Atas Penggajian

awan.

wanto

al Considerations for Preparing E-Collaborative Research

ementation

etam Rizky Wicaksono

\section{AYA, BAHASA, DAN TEKNOLOGI PEMBELAJARAN}

acter Building Through Foreign Language Teaching

Igenius Sadtono

Jile of Teaching Performances and Efforts to Upgrade

yogical Skills at Ma Chung University.

itrisius Istiarto Djiwandono

g Chatrooms to Enhance Students' Learning Autonomy oss-cultural Understanding Subject.

idi Setyaningsih

Learning or Meaningful Learning

mald Keeler

ligence and Education

Yun Lin

al Interests, Local Profits
Hughes' Poems Reflecting Racial Discrimination in Employment Global Interests.

Lilis Lestari Wilujeng

How to Enhance Student's Speaking Communicative

Competence in Chinese?

cong Ye

A Brief Discussion on Setting Chinese Homeworks in Ma Chung

University

Huang Shiru

Brief Discussion on Some of The Understanding and Points of View Regarding Teaching Chinese Classical Poems to Foreign Mandarin Beginners.

Yang Min

Simple Analysis of How to Apply Games into Teaching Chinese

as a Second Language.

Liang Jin Feng

yrte de vos 


\title{
Social Considerations for Preparing E-Collaborative Research Implementation
}

\author{
Soetam Rizky Wicaksono ${ }^{1 *}$ \\ ${ }^{1}$ Lecturer of the Information System Study Program Ma Chung University \\ *Email: soetam.rizky@machung.ac.id
}

\section{Abstract}

Research in higher education is very minimum in its amount, especially when it comes into collaborative research. However, many researchers try to solve it using e-collaborative research which can handle time and distance barriers. This analytical research tries to dig deep down of social considerations as ecollaborative research being prepared in higher education environment. The results of this research has concluded that social ties, extrinsic motivation, workspace awareness and collaborative exchange can be main factors for researchers to create succesful e-collaborative research despite of technical considerations.

Keywords: e-collaborative, social,research

\section{Introduction}

Research as one of the main activity in a higher education environment particularly in Indonesia which already emphasized as one of tri dharma obligation for lecturer. However, it is already proven empirically that lecturers' research in Indonesia is very minimum in its amount (Kompas, 2008). Thus there must be some innovative way which must be provided by university in order to increase lecturers productivity in research activity.

Some universities try to increase it using internal grant competition or merely forcing their lecturers to create research. On the other hand, government through DIKTI has also try to increase it using many ways uch as grant activity (hibah) or also many kinds of rewards (buku ajar, anugerah kekayaan intelektual and so on). But still, the increment of lecturers' research in Indonesia is still pathetic. 
This research try to explore the social aspects of using collaborative work in virtual way for research activity or commonly named as eas already being proven as

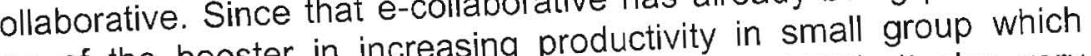
one of the booster in increasing (Rutkowski et al, 2002). It also very needed to have improvement (Rutkowski et al, al, 2009).

However, implementation of e-collaborative in each organization need special treatment in order to gain better achievement. While the echnical approach of e-collaborative implementation has already been proven not becoming the main factor of failure (Sonnenwald, 2009: Kotlarsky \& Oshri, 2005; Rutkowsky et al, 2002), therefore this

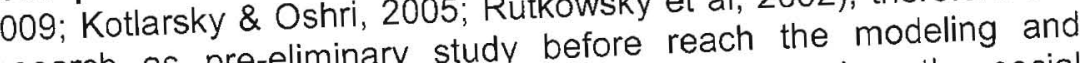
research as pre-eliminary study before reach the explore the social aspects in preparing the implementation groupware as e-collaborative in research activity.

\section{E-Collaborative}

The word collaboration comes from the Latin words com (prefix anorare (verb to work). It means that two or more individuals work jointly on an intellectual endeavour (Webster, 1992). Collow means that a process by which individuals and/or groups work together on a practical endeavor collaborative work is a fundamental feature of organizations and is increasingly being supported by technology (Fong,2005). The term of e-collaborative also can be defined as a framework which can create a collaborative situation in certain situation using web based application. The implementation of e-collaborative commonly done using
groupware. Since that one of main characteristic of groupware is groupware. Since that one of main chance to take part in activity
making all group members get a chance
(Manning \& Riordan, 2000), therefore it should be fit in the (Manning \& Riordan, 2000), therefore
implementation of e-collaborative. On the other hand, collaborative
process which include knowledge sharing has already been proven empirically as one of the factor in contributing successfulnes it collaboration result (Kotlarsky \& Oshri, 2005).

\section{Social Considerations in E-Collaborative Research Implementation}

Implementing E-Collaborative in research field in one of the option while many researchers commonly spread up in different area. This kind of situation should not stumbling block the collaboration process since that they can create a virtual team to solve this problem. However, this implementation has block factors which can deny its main goal, and also has some boost factors which can drive the achievement.

First of all, in implementing e-collaborative there is possibility of wicked user behaviour named as free riders (Kotlarsky \& Oshri, 2005). This behavior comes from users who just try to put their name in paper but never or rarely contribute to the e-collaborative. However, this behavior rarely shown in collaborative research since that the members of research group really need high acknowledgement rather than just trying to put their names as a credit in research title (Sonnenwald et al, 2005).

Despite of free rider behavior that could bother the accomplishment of e-collaborative research, there are some empirical studies has already tried to reduce this such behavior using specific factors. These factors are :

a. Social ties (Kotlarsky \& Oshri, 2005)

The need of social ties between researchers, particularly for lecturers in Indonesia, can be an important factor in supporting the achievement of e-collaborative research. However, since that social ties between researchers in Indonesia mostly become tighter merely by the similar institution or place. This happen because there is still cultural gap between "junior-senior relationship" in researchers environment. Thus, this social ties factor can only become success factor only in an institution whenever e-collaborative research being implemented.

b. Mixed presence implementation (Tang, Boyle \& Greenberg, 2004)

Mixed presence means that all the participants not only collaborating using the groupware or individual display in remote places, but it also having face to face meeting periodically in 
order to solve the problem. This kind of implementation can also become one of success factor beside the other has mentioned previously. Mixed presence not merely force all the ecollaborative members become active contributor (or avoiding free rider behavior), but it also can boost the result of collaborative research. It occurs because of whenever one of the member stucks in the middle of collaborative research process or just trying to become a free rider, then mixed presence should make a distinction between the active and inactive member, thus the collaborative process will get bact in the track again.

c. Workspace awareness (Gutwin \& Greenberg, 1999)

One important thing in collaboration that every member should know is their role in the collaborative process. Particularly in ecollaborative research which commonly involved many researchers from different theoritical background. Thus, every member should know where to start and when to finish their role part in order to allow others do their next part. This kind of awareness should be assigned by the team leader and must be obeyed by the member in order to optimize the result of ecollaborative research.

d. Collective exchange approach (Sonnenwald et al, 2005)

Since that each researcher commonly has their own tacit knowledge, then they should have done knowledge exchange in collaborative process. When this exchange occur in ecollaborative system, then it will become a collective knowledge exchange before the member can really realize it. This situation can be one of success factor in e-collaborative research implementation, because each member will feel that they get new knowledge and also sharing theirs to others. Thus it will motivate them to contribute more in system while they got hidden acknowledgement from their peers after exchange their knowledge through collaboration.

e. Extrinsic motivation (Shapira, Kantor \& Melamed, 2001)

The last factor which could affect most of the members named as extrinsic motivation. In an empirical study from Shapira et al, has already conclude that extrinsic motivation such as reward, money and promotion have become main factor for member in contributing their role better. Surely this factor can only happen when the research being conducted by certain institution with huge fund in it. It also can happen when the research become obligatory in the institution for the researcher in order to gain certain position or certain reward (in Indonesia commonly researchers who also lecturer try to achieve credit point for their JAFA (Jabatan fungsional akademik) which can give them money reward in the future).

\section{Conclusion}

After exploring some social consideration in preparing e-collaborative research implementation, surely there are some reasonable and logic thought which can be determined. First of all, it better implement ecollaborative research merely in single institution or university to gain better result. Since that the social ties between researchers usually strong in their own "nest", however, the purpose of e-collaborative research is to create more researchers involved in a research theme. Thus it should be continued the e-collaborative not merely in an institution but also create a "real collaboration" among other institution.

It also empirically proven that researchers as "intelectual club members" need a hidden acknowledgement from their contribution in e-collaborative research. Thus, the team leader should become a really smart one in order to create a competitive situation among researchers. The situation then should force the team members exchanging their tacit knowledge unintentionally and becoming aware of their roles in order to finish the research goal.

Last but not least, the research which being conducted in ecollaborative environment should include extrinsic motivation such as fund, certain reward or particular achievement for the team member Since that extrinsic motivation can become the great teaser for all member to exploit each of their ability in collaborative process.

\section{Future Attention}

While this research merely focus on social factor before the ecollaborative research being implemented, it should also considering the technical factor which can be constraint in it. Afterward, all the pre- 
virtual research environments in library and information science. Library Hi Tech, 27(2), 191-204. Retrieved November 1, 2010 from Research Library. (Document ID: 1879688421)

Tang, Anthony, Michael Boyle, and Saul Greenberg,2004, Display and presence disparity in Mixed Presence Groupware. In Proceedings of the fifth conference on Australasian user interface - Volume 28 (AUIC '04), A. Cockburn (Ed.), Vol. 28. Australian Computer Society, Inc., Darlinghurst, Australia, Australia, 73-82 Webster, 1992, Webster's Dictionary, Oxford University Press, Oxford 2008, Kurang dari 10 Persen Dosen yang Lakukan Penelitian,

Kompas, 11 Desember 2008

Fong, Michelle W.L, 2005, E-collaborations and virtual organizations, IRM Press

Gutwin, Carl and Saul Greenberg, 1999. The effects of workspace awareness support on the usability of real-time distributed groupware. ACM Trans. Comput.-Hum. Interact. 6, 3 (September 1999), 243-281. DOI=10.1145/329693.329696

Kotlarsky, Julia \& Ilan Oshri, 2005, Social ties, knowledge sharing and successful collaboration in globally distributed system development projects. European Journal of Information Systems: Special issue: from technical to socio-technical change:, 14(1), 37. Retrieved November 23, 2010, from Research Library. (Document ID: 1004391171)

Manning, Linda M \& Catherine A Riordan, 2000, Using groupware software to support collaborative learning in economics, Journal of Economic Education; Summer 2000; 31, 3; Research Library pg. 244

Rutkowski, A.-F. , D. Vogel, T.M.A. Bemelmans, \& M. van Genuchten, 2002, Group Support Systems and Virtual Collaboration: The HKNET Project. Group Decision and Negotiation, 11(2), 101-125. Retrieved November 1, 2010, from Research Library. (Document ID: 403883851)

Shapira, Bracha, Paul B Kantor, \& Benjamin Melamed, 2001, The effect of extrinsic motivation on user behavior in a collaborative information finding system. Journal of the American Society for Information Science and Technology, 52(11), 879-887. Retrieved November 23, 2010, from Research Library. (Document ID: 79609584)

Sonnenwald, Diane H. , Monica Lassi, Nasrine Olson, Marisa Ponti, \& Ann-Sofie Axelsson, 2009, Exploring new ways of working using 